\title{
It is not polite to ask a dialysis patient his age!
}

\author{
Anuja Shah • Miklos Z. Molnar • \\ Kamyar Kalantar-Zadeh
}

Received: 2 April 2011/Accepted: 7 April 2011/Published online: 6 May 2011

(C) Springer Science+Business Media, B.V. 2011

So-called "seniors", i.e., those older than 65 years, constitute the fastest growing population group in United States. According to the 2008 United States census bureau report, the number of elders grew from 29.6 million in 1990 to 36.8 million in 2008, representing a $20 \%$ incremental growth (http://www. census.gov). Consequent to the absolute increase in elderly individuals in the population pyramid, the prevalence and incidence of chronic disease states, such as hypertension, diabetes mellitus, coronary

A. Shah · M. Z. Molnar - K. Kalantar-Zadeh Harold Simmons Center for Chronic Disease Research \& Epidemiology, Los Angeles Biomedical Research Institute at Harbor-UCLA Medical Center, Torrance, CA, USA

A. Shah · K. Kalantar-Zadeh $(\square)$

Division of Nephrology and Hypertension, Harbor-UCLA Medical Center, 1124 West Carson Street, C1-Annex, Torrance, CA 90509-2910, USA

e-mail: kamkal@ucla.edu

\section{Z. Molnar}

Institute of Pathophysiology, Semmelweis University, Budapest, Hungary

K. Kalantar-Zadeh

David Geffen School of Medicine at UCLA, Los Angeles, CA, USA

K. Kalantar-Zadeh

Department of Epidemiology, UCLA School of Public Health, Los Angeles, CA, USA artery disease, heart failure, and chronic kidney disease (CKD), have also risen in the overall population [1-3]. In particular, CKD including the endstage renal disease (ESRD) has reached pandemic dimensions and is quite common in the elderly [4]. Currently, over $50 \%$ of dialysis patients in United States and Canada are older than 60 years [5]. There is an ongoing discussion as to whether the clinical outcomes of renal replacement therapy including dialysis treatment and kidney transplantation justify these expensive therapy modalities in the elderly. Three important clinical outcomes of interest include mortality, hospitalization, and health-related quality of life (HRQoL).

In this current study by Sun et al. [6], the outcome of hospitalization in the elderly on dialysis was nicely highlighted. The results of the study by Sun et al. may be summarized as follows: incident hemodialysis patients (over a 15 year period) who had follow up for at least 6 months were analyzed for the number of hospitalizations per person year. They were divided into 3 groups: those over 70 (group A), those less than 70 for the entire study period (group B), and those less than 70 at the beginning of the study period but over 70 at the end of the HD period (group C). No differences were found between younger and older dialysis patients in the overall number of hospitalizations. A total of 412 patients were analyzed, 44 of whom were over the age of 80 . Of note, group A contained a lower percent of diabetics; they were 20 years older on average and had a lower 
compliance with their HD schedule (defined as missing 2 or more of HD days monthly). There were a higher number of hospitalizations for surgery and trauma in group A compared to group B. For vascular access issues, advanced age at onset of dialysis became significant with logarithmic transformation of the data for admission rate and number of hospital days. With linear but not logarithmic interpretation of the data, advanced age at the start of dialysis was a predictor for non-vascular related hospitalization rates and number of days [6]. Thus, the outcome of hospitalization rate is not a distinguishing factor between the elderly and those not on dialysis.

The elderly do have a higher degree of morbidity and mortality in many health conditions [7]. Previous studies by Tzamloukas et al. have demonstrated age to be an independent risk factor for death during hospitalization [8]. Hospitalization rates are part of the assessment of HRQoL and morbidity and as such the rate of hospitalization in an important factor to be considered in decisions made whether or not to dialyze patients. The RPA/ASN guidelines state that it is "appropriate to say "no"" to dialyzing patients who have an extremely poor prognosis. The populations the guidelines address include those with low albumins, low functional status, and comorbid conditions [9]. The Charlson Comorbidity Index, which was designed to predict mortality during hospitalization, is a commonly used tool to quantify comorbidity; it includes age (for each decade above 40, a score of one is added) [10]. Thus, advancing age is an inherent issue in the current view of assessment for suitability for dialysis. Recent papers have addressed the futility in placing accesses in those with advanced age with multiple comorbidities [11] and have given credence to the option of conservative management in select cases [55]. In our attempt to contain health care costs and to maximize benefits of the care we do provide, the elderly have become a vulnerable population. Age is an objective and easily quantified factor. Unfortunately, it does not encompass a large part of what it means to live well, and so to use it as an independent factor in not offering therapy may lead to a slippery slope.

Mortality is an inescapable issue in this debate. Data from the United States Renal Data System (USRDS) indicate that patients aged 65 or older undergoing dialysis have a median life expectancy of approximately 4 years, which is markedly lower than that of a patient of the same age without ESRD [12]. In a Canadian study of ESRD patients older than 75 years, survival at 1, 3, and 5 years was $69 \%, 37 \%$, and $20 \%$ respectively $[13,14]$. Nevertheless, some observational studies have found significantly greater survival of those elderly ESRD patients who initiated dialysis versus those treated conservatively [15-17]. It is not clear, however, which dialysis modality is better for elderly patients. In one study, the relative risk for death was higher among elderly diabetics undergoing peritoneal dialysis (PD) than those on hemodialysis [18], whereas several other studies found no difference between the two modalities [19, 20] including among elderly diabetics [19]. Notwithstanding such inconsistent data, PD still appears to be an appropriate dialysis option for elderly ESRD patients [7, 21].

Kidney transplantation is another renal replacement therapy in lieu of dialysis and is believed to improve HRQoL and survival in ESRD patients [22]. Factors associated with mortality, such as residual renal function, previous time on dialysis, sleep disorders or bone and mineral metabolism disorders [23-26], might be also associated with HRQoL in kidney transplanted patients [23]. Moreover, HRQoL is an important predictor of outcomes in kidney transplanted patients [27]. Kidney transplantation is the treatment of choice for most ESRD patients independent of age [28-30]. However, the generalizability of the studies comparing survival after renal transplantation with dialysis therapy is compromised by such methodological flaws as selection bias [31, 32]. Studies with fewer methodological limitations indicate a survival advantage with transplantation among the elderly including recipients of "extended criteria donor" kidneys, when compared to dialyzed elderly patients [29, 33-37]. Wolfe et al. [29] compared the survival of primary deceased donor transplant recipients with other dialysis patients and found that among renal transplant recipients patients aged 60-74 years, the cumulative survival rate improved after the first year post-transplantation. More recent studies indicate that in elderly ESRD patients, survival at 1,5 , and 10 years is approximately $80 \%$ to $90 \%, 70 \%$, and $50 \%$ respectively [3846]. In the United States there are currently over 16,000 ESRD patients older than 65 years waiting for a kidney transplantation, representing $18 \%$ of all listed candidates [1]. Some studies have attempted to 
identify factors that would predict outcomes in elderly kidney transplanted recipients. Most recently, Heldal et al. [47] found that acute rejection in the first 90 days, and donor age $\geq 60$ years predicted lower patient survival; whereas delayed graft function, donors aged 60 years or older, and HLA antibodies were associated with increased death-censored graft loss. Gill et al. [48] found that elderly recipients of transplanted kidneys from living donors aged $>55$ years had inferior 3-year graft survival (86\%) but similar 3-year patient survival rates $(88 \%)$ when compared to their transplanted counterparts with living donors $\leq 55$ years.

The greater goal of medicine is to improve the lives of our patients. Placing hospitalization rates and mortality in this context is pragmatic. The World Health Organization defines the quality of life (QoL) as an "individual's perception of their position in life in the context of the culture and value systems in which they live and in relation to their goals, expectations, standards and concerns". The term health-related QoL pertains to both physical and psychological factors that are related to health status [49]. The Institute of Medicine defines the quality of care as the degree to which health care services for individuals and populations increase the likelihood of desired health outcomes and are consistent with current professional knowledge [50]. The challenge for nephrologists is to provide high quality of care that also improves HRQoL in a cost-effective manner. Given the rising size of the ESRD population, the growing burden of ESRD demands that quality of care meet its cost. In 1994, the Institute of Medicine held a workshop to generate a guide to assess quality of care in dialysis patients and to include HRQoL measures [51]. The workshop highlighted the need to include functional status, patient satisfaction, well-being, and health status independently. Attention to details beyond short-term clinical outcomes and survival has been commonly dismissed. Patient experience needs to be central to quality of care measurements and health decisions. This broad approach to evaluating health care is also needed for the elderly on dialysis, as well as for any individuals with a chronic disease state.

The elderly with kidney disease are a very special population. The HRQoL in the elderly has been shown to be affected by functional status, nutritional status, and a sense of independence, among other clinical parameters [52]. Issues that are important for the general population of the elderly are important in ESRD as well. Dementia has been shown to have a similar prevalence in the elderly with ESRD relative to the population [53]. Nutrition is part of daily life, and impaired nutrition does decrease HRQoL [54-56]. This is not unique to the ESRD population, but nephrologists may be uniquely capable of addressing this issue in CKD patients [57]. In the study by Sun et al. [6], the HRQoL was not measured directly. Hospitalization rates, as an important determinant of HRQoL, were examined and not increased in the elderly on dialysis. These results are supported by previous studies including those by Lamping et al. [58], who found that in a group of incident elderly patients on dialysis, a comorbidity assessment was a better independent predictor of mortality than age alone. In the latter study, 30 percent of patients over age 70 did not require hospitalization in a 1-year span. More importantly, measures of mental quality of life in their elderly dialysis patients were similar to those in elderly people in the general population [58]. In both studies, age did not decrease QoL by increasing hospitalizations.

The study by Sun et al. [6] is both a demonstration of how our view toward the elderly on dialysis should shift, and a reminder of the gaps in our evaluation of quality of care in the elderly on dialysis. Those elderly that are well enough to survive CKD to reach ESRD may be a naturally selected population capable of doing well on renal replacement therapy. Since age is part of our scoring for comorbidities, we might give it over-importance and ration health care away from those who may benefit from it. And, as we tend to focus on easily measurable, clinically focused items (i.e. age and hospitalization rates), we exclude the importance of the patient experience, which may be independent of age. Choosing whom "to say 'no' to," will likely not be well defined by a simple number, but will need a comprehensive assessment of the patient's goals and abilities, as well as the capabilities of our current therapies to serve them.

\section{References}

1. Goldberg RJ, Spencer FA, Farmer C, Meyer TE, Pezzella S (2005) Incidence and hospital death rates associated with 
heart failure: a community-wide perspective. Am J Med 118:728-734

2. Cowie CC, Rust KF, Ford ES, Eberhardt MS, Byrd-Holt DD, Li C, Williams DE, Gregg EW, Bainbridge KE, Saydah SH, Geiss LS (2009) Full accounting of diabetes and pre-diabetes in the US population in 1988-1994 and 2005-2006. Diabetes Care 32:287-294

3. Ong KL, Cheung BM, Man YB, Lau CP, Lam KS (2007) Prevalence, awareness, treatment, and control of hypertension among United States adults 1999-2004. Hypertension 49:69-75

4. Paraskevas KI, Bessias N, Koupidis SA, Tziviskou E, Mikhailidis DP, Oreopoulos DG (2010) Incidence of endstage renal disease in the elderly: a steadily rising global socioeconomic epidemic. Int Urol Nephrol 42:523-525

5. US Renal Data System: USRDS 2010 Annual data report (2010) Atlas of chronic kidney disease and end-stage renal disease in the United States. In: Bethesda MD (ed)Institutes of Health, National Institute of Diabetes and Digestive and Kidney Diseases

6. Sun Y, Kassam H, Adeniyi M, Martinez M, Agaba EI, Onime A, Servilla KS, Raj DSC, Murata GH, Tzamaloukas AH (2011) Hospital admissions in elderly patients on chronic hemodialysis. Int Urol Nephrol. doi:10.1007/ s11255-011-9913-1

7. Yang X, Fang W, Kothari J, Khandelwal M, Naimark D, Jassal SV, Bargman JM, Oreopoulos DG (2007) Clinical outcomes of elderly patients undergoing chronic peritoneal dialysis: experiences from one center and a review of the literature. Int Urol Nephrol 39:1295-1302

8. Behl M, Sun Y, Agaba EI, Martinez M, Servilla KS, Raj DS, Murata GH, Tzamaloukas AH (2010) Death during hospitalization in patients on chronic hemodialysis. Hemodial Int 14(Suppl 1):S14-S21

9. Moss AH (2001) Shared decision-making in dialysis: the new RPA/ASN guideline on appropriate initiation and withdrawal of treatment. Am J Kidney Dis 37:1081-1091

10. Charlson ME, Pompei P, Ales KL, MacKenzie CR (1987) A new method of classifying prognostic comorbidity in longitudinal studies: development and validation. J Chronic Dis 40:373-383

11. Demoulin N, Beguin C, Labriola L, Jadoul M (2011) Preparing renal replacement therapy in stage $4 \mathrm{CKD}$ patients referred to nephrologists: a difficult balance between futility and insufficiency. A cohort study of 386 patients followed in Brussels. Nephrol Dial Transplant 26: 220-226

12. United States Renal Data System. Excerpts from USRDS 2009 Annual data report (2010) US department of health and human services. The National Institutes of Health, National Institute of Diabetes and Digestive and Kidney Diseases. Am J Kidney Dis, pS1

13. Letourneau I, Ouimet D, Dumont M, Pichette V, Leblanc M (2003) Renal replacement in end-stage renal disease patients over 75 years old. Am J Nephrol 23:71-77

14. Jassal SV, Trpeski L, Zhu N, Fenton S, Hemmelgarn B (2007) Changes in survival among elderly patients initiating dialysis from 1990 to 1999. CMAJ 177:1033-1038

15. Busuioc M, Gusbeth-Tatomir P, Covic A (2008) Dialysis or not in the very elderly ESRD patient. Int Urol Nephrol 40:1127-1132
16. Carson RC, Juszczak M, Davenport A, Burns A (2009) Is maximum conservative management an equivalent treatment option to dialysis for elderly patients with significant comorbid disease? Clin J Am Soc Nephrol 4:1611-1619

17. Murtagh FE, Marsh JE, Donohoe P, Ekbal NJ, Sheerin NS, Harris FE (2007) Dialysis or not? A comparative survival study of patients over 75 years with chronic kidney disease stage 5. Nephrol Dial Transplant 22:1955-1962

18. Bloembergen WE, Port FK, Mauger EA, Wolfe RA (1995) A comparison of mortality between patients treated with hemodialysis and peritoneal dialysis. J Am Soc Nephrol 6:177-183

19. Jaar BG, Coresh J, Plantinga LC, Fink NE, Klag MJ, Levey AS, Levin NW, Sadler JH, Kliger A, Powe NR (2005) Comparing the risk for death with peritoneal dialysis and hemodialysis in a national cohort of patients with chronic kidney disease. Ann Intern Med 143:174-183

20. Foley RN, Parfrey PS, Harnett JD, Kent GM, O’Dea R, Murray DC, Barre PE (1998) Mode of dialysis therapy and mortality in end-stage renal disease. J Am Soc Nephrol 9:267-276

21. Dimkovic N, Oreopoulos DG (2008) Assisted peritoneal dialysis as a method of choice for elderly with end-stage renal disease. Int Urol Nephrol 40:1143-1150

22. Kovacs AZ, Molnar MZ, Szeifert L, Ambrus C, MolnarVarga M, Szentkiralyi A, Mucsi I, Novak M (2011) Sleep disorders, depressive symptoms and health-related quality of life-a cross-sectional comparison between kidney transplant recipients and waitlisted patients on maintenance dialysis. Nephrol Dial Transplant 26:1058-1065

23. Molnar MZ, Novak M, Mucsi I (2009) Sleep disorders and quality of life in renal transplant recipients. Int Urol Nephrol 41:373-382

24. Remport A, Keszei A, Vamos EP, Novak M, Jaray J, Rosivall L, Mucsi I, Molnar MZ (2011) Association of pretransplant dialysis duration with outcome in kidney transplant recipients: a prevalent cohort study. Int Urol Nephrol 43:215-224

25. Remport A, Molnar MZ, Ambrus C, Keszei A, Torok S, Vamos EP, Kiss I, Jaray J, Novak M, Rosivall L, Mucsi I (2010) Impaired renal function is associated with mortality in kidney-transplanted patients. Int Urol Nephrol 42: 799-809

26. Ambrus C, Molnar MZ, Czira ME, Rosivall L, Kiss I, Remport A, Szathmari M, Mucsi I (2009) Calcium, phosphate and parathyroid metabolism in kidney transplanted patients. Int Urol Nephrol 41:1029-1038

27. Molnar-Varga M, Molnar MZ, Szeifert L, Kovacs AZ, Kelemen A, Becze A, Laszlo G, Szentkiralyi A, Czira ME, Mucsi I, Novak M (2011) Health related quality of life and clinical outcomes in kidney transplanted recipients. Am J Kidney Dis (in press)

28. Mohamed Ali AA, Abraham G, Khanna P, Reddy YN, Mehrotra A, Mathew M, Sundararaj S, Jasmine R (2011) Renal transplantation in the elderly: South Indian experience. Int Urol Nephrol 43:265-271

29. Wolfe RA, Ashby VB, Milford EL, Ojo AO, Ettenger RE, Agodoa LY, Held PJ, Port FK (1999) Comparison of mortality in all patients on dialysis, patients on dialysis awaiting transplantation, and recipients of a first cadaveric transplant. N Engl J Med 341:1725-1730 
30. Saxena R, Yu X, Giraldo M, Arenas J, Vazquez M, Lu CY, Vaziri ND, Silva FG, Zhou XJ (2009) Renal transplantation in the elderly. Int Urol Nephrol 41:195-210

31. Taube DH, Winder EA, Ogg CS, Bewick M, Cameron JS, Rudge CJ, Williams DG (1983) Successful treatment of middle aged and elderly patients with end stage renal disease. British medical journal (Clinical research ed) 286 : 2018-2020

32. Fauchald P, Albrechtsen D, Leivestad T, Berg KJ, Talseth T, Flatmark A (1988) Renal replacement therapy in elderly patients. Transpl Int 1:131-134

33. Johnson DW, Herzig K, Purdie D, Brown AM, Rigby RJ, Nicol DL, Hawley CM (2000) A comparison of the effects of dialysis and renal transplantation on the survival of older uremic patients. Transplantation 69:794-799

34. Oniscu GC, Brown H, Forsythe JL (2004) How great is the survival advantage of transplantation over dialysis in elderly patients? Nephrol Dial Transplant 19:945-951

35. Giessing M, Budde K, Fritsche L, Slowinski T, Tuerk I, Schoenberger B, Neumayer HH, Loening SA (2003) "Oldfor-old" cadaveric renal transplantation: surgical findings, perioperative complications and outcome. Eur Urol 44: 701-708

36. Rao PS, Merion RM, Ashby VB, Port FK, Wolfe RA, Kayler LK (2007) Renal transplantation in elderly patients older than 70 years of age: results from the Scientific Registry of Transplant Recipients. Transplantation 83: 1069-1074

37. Savoye E, Tamarelle D, Chalem Y, Rebibou JM, Tuppin P (2007) Survival benefits of kidney transplantation with expanded criteria deceased donors in patients aged 60 years and over. Transplantation 84:1618-1624

38. Velez RL, Brinker KR, Vergne-Marini PJ, Nesser DA, Long DL, Trevino G, Dickerman RM, Helfrich GB (1991) Renal transplantation with cyclosporine in the elderly population. Transpl Proc 23:1749-1752

39. Morris GE, Jamieson NV, Small J, Evans DB, Calne R (1991) Cadaveric renal transplantation in elderly recipients: is it worthwhile? Nephrol Dial Transplant 6:887-892

40. Doyle SE, Matas AJ, Gillingham K, Rosenberg ME (2000) Predicting clinical outcome in the elderly renal transplant recipient. Kidney Int 57:2144-2150

41. Saudan P, Berney T, Leski M, Morel P, Bolle JF, Martin PY (2001) Renal transplantation in the elderly: a longterm, single-centre experience. Nephrol Dial Transplant 16:824-828

42. Bentas W, Jones J, Karaoguz A, Tilp U, Probst M, Scheuermann E, Hauser IA, Jonas D, Gossmann J (2008) Renal transplantation in the elderly: surgical complications and outcome with special emphasis on the Eurotransplant Senior Programme. Nephrol Dial Transplant 23:2043-2051

43. Oniscu GC, Brown H, Forsythe JL (2004) How old is old for transplantation? Am J Transplant 4:2067-2074

44. Fabrizii V, Winkelmayer WC, Klauser R, Kletzmayr J, Saemann MD, Steininger R, Kramar R, Horl WH, Kovarik J (2004) Patient and graft survival in older kidney transplant recipients: does age matter? J Am Soc Nephrol 15: 1052-1060

45. Kauffman HM, McBride MA, Cors CS, Roza AM, Wynn JJ (2007) Early mortality rates in older kidney recipients with comorbid risk factors. Transplantation 83:404-410
46. Tesi RJ, Elkhammas EA, Davies EA, Henry ML, Ferguson RM (1994) Renal transplantation in older people. Lancet 343:461-464

47. Heldal K, Hartmann A, Leivestad T, Svendsen MV, Foss A, Lien B, Midtvedt K (2009) Clinical outcomes in elderly kidney transplant recipients are related to acute rejection episodes rather than pretransplant comorbidity. Transplantation 87:1045-1051

48. Gill J, Bunnapradist S, Danovitch GM, Gjertson D, Gill JS, Cecka M (2008) Outcomes of kidney transplantation from older living donors to older recipients. Am J Kidney Dis 52:541-552

49. World Health Organization (1994) Quality of life assessment: an annotated bibliography. Geneva: WHO (WHO/ MNH/PSF/94.1). http://whqlibdoc.who.int/hq/1994/WHO_ MNH_PSF_94.1.pdf

50. Medicine Io (1990) Medicare: a strategy for quality assurance, volume II: sources and methods. In: Lohr KN (ed). National Academy Press, Washington

51. Rettig RA, Sadler JH, Meyer KB, Wasson JH, Parkerson GR Jr, Kantz B, Hays RD, Patrick DL (1997) Assessing health and quality of life outcomes in dialysis: a report on an Institute of Medicine workshop. Am J Kidney Dis 30: 140-155

52. Oreopoulos A, Kalantar-Zadeh K, Sharma AM, Sharma AM, Fonarow GC (2009) The obesity paradox in the elderly: potential mechanisms and clinical implications. Clin Geriatr Med 25:643-659 viii

53. Kurella M, Mapes DL, Port FK, Chertow GM (2006) Correlates and outcomes of dementia among dialysis patients: the dialysis outcomes and practice patterns study. Nephrol Dial Transplant 21:2543-2548

54. Rambod M, Bross R, Zitterkoph J, Benner D, Pithia J, Colman S, Kovesdy CP, Kopple JD, Kalantar-Zadeh K (2009) Association of malnutrition-inflammation score with quality of life and mortality in hemodialysis patients: a 5-year prospective cohort study. Am J Kidney Dis 53:298-309

55. Noori N, Kopple JD, Kovesdy CP, Feroze U, Sim JJ, Murali SB, Luna A, Gomez M, Luna C, Bross R, Nissenson AR, Kalantar-Zadeh K (2010) Mid-arm muscle circumference and quality of life and survival in maintenance hemodialysis patients. Clin J Am Soc Nephrol 5:2258-2268

56. Kalantar-Zadeh K, Kuwae N, Wu DY, Shantouf RS, Fouque D, Anker SD, Block G, Kopple JD (2006) Associations of body fat and its changes over time with quality of life and prospective mortality in hemodialysis patients. Am J Clin Nutr 83:202-210

57. Bilgic A, Akgul A, Sezer S, Arat Z, Ozdemir FN, Haberal M (2007) Nutritional status and depression, sleep disorder, and quality of life in hemodialysis patients. J Ren Nutr 17: 381-388

58. Lamping DL, Constantinovici N, Roderick P, Normand C, Henderson L, Harris S, Brown E, Gruen R, Victor C (2000) Clinical outcomes, quality of life, and costs in the North Thames dialysis study of elderly people on dialysis: a prospective cohort study. Lancet 356:1543-1550 